\title{
Physicochemical characteristics and antioxidant activity of the organic green peppers
}

\author{
Min-Sun Chang ${ }^{1}$, Moon-Cheol Jeong ${ }^{2}$, Gun-Hee Kim ${ }^{1 *}$ \\ ${ }^{1}$ Plant Resources Research Institute, DukSung Women's University, Seoul 01369, Korea \\ ${ }^{2}$ Korea Food Research Institute, Seongnam 13539, Korea
}

\section{유기농 풋고추의 이화학적 특성 및 항산화활성}

\author{
장민선 ${ }^{1} \cdot$ 정문철 $^{2} \cdot$ 김건희 $^{1 *}$ \\ ${ }^{1}$ 덕성여자대학교 식물자원연구소, ${ }^{2}$ 한국식품연구원
}

\begin{abstract}
As consumers are aware of their health and are more conscious of environmental conditions, there is an increasing demand for organic agri-foods. The present study aims to investigate the physicochemical quality characteristics and antioxidant activity of organic green peppers. The weight, length, moisture content, color (Hunter L, a, b) and hardness were measured for the quality characteristics. In addition, the DPPH, ABTS radical scavenging activities and total phenolic contents were analyzed for the comparison of antioxidant activities between organically and conventionally grown green peppers. The weight and length of the organically grown green peppers were lower than those of the conventionally grown ones. The moisture content of the organically and conventionally grown green peppers was similar. The $L$ and $b$ values of the organically grown green peppers were higher than those of the conventionally grown ones. The DPPH radical scavenging activity of the organically grown green peppers $(62.86 \%)$ was higher than that of the conventionally grown ones $(51.06 \%)$. The total phenolic content of the organically grown green peppers was higher than that of the conventionally grown ones, however, there was no significant differences between organically and conventionally grown green peppers $(\mathbf{p}<0.05)$. Further studies would be recommended for the evaluation of other characteristics such as flavor, taste, and bioactivity compounds between organically and conventionally grown green peppers.
\end{abstract}

Key words : organic, quality, color, antioxidant, green pepper

\section{서 론}

국민 소득과 생활수준이 향상되면서 식품의 안전성에 대한 소비자의 인식이 높아짐에 따라 친환경농산물의 선호 도가 증가하고 있다. 1990년대 이후 세계적으로 친환경 농 업이 확산됨과 더불어 한국에서도 2010년 기준 친환경농산 물의 출하량 비중이 전체 농산물 출하량의 약 $12 \%$ 에 달하

*Corresponding author. E-mail : ghkim@duksung.ac.kr Phone : 82-2-901-8496, Fax : 82-2-901-8474

Received 16 June 2015; Revised 1 August 2015; Accepted 7 August 2015.

Copyright (c) The Korean Society of Food Preservation. All rights reserved.
고 있으며 친환경농산물 시장의 거래규모는 2000년에 1,500 억 원 수준에서 2005년에 7,800억 원, 2010년에 3조 6,506억 원으로 크게 증가해온 것으로 추정된다(1).

유기농이란 농약이나 화학비료를 사용하지 않고, 유기질 만을 사용하여 재배한 본연의 농산물(2)을 말하며 일반재배 와 비교하여 병해충 발생률이 증가하지만 이를 통한 환경적 스트레스 기작으로 인하여(3) 우리 몸에 이로운 폴리페놀, 비타민 C 등과 같은 2 차 대사산물이 형성될 수 있다(4) 유기농산물은 농약 및 화학비료 사용에 대한 거부감을 약화 시키는 장점이 있는 반면 외관이 불량해지는 단점과 함께 소비자 인식에서 높은 가격대비 품질, 외관, 맛 등에 대한 낮은 신뢰도로 유기농산물의 경쟁력 확보에 다소 어려움이 있는 실정이다(5-7). 따라서 유기농산물의 소비 증대 및 신 
뢰 재고를 위해 소비자 단계에서의 유기재배 농산물에 대한 품질을 확인하여 볼 필요가 있다.

국내의 경우 유기농산물과 관련한 대다수의 연구주제가 유기농식품의 재배기술(8)에 집중되어 있고, 품질에 대한 연구는 주로 미생물 분석 $(9,10)$ 및 중금속 함량 분석(11), 잔류농약(12) 등의 유해물질 분석과 같은 안전성 연구에 맞춰져 있으며 유기 및 일반 농산물의 품질특성을 비교한 연구는 미흡한 실정이다. 또한, 현재 유기농산물은 일반재 배 품목에 비해 높은 가격으로 판매되고 있으나 수확 후 유기농산물의 품질에 대한 정보는 전무한 상태다. 이에 유 기농산물 품질과 관련한 많은 연구가 진행될 필요가 있다. 풋고추는 우리나라 사람들이 매우 즐기는 채소 중 하나 로(13) 식재료로 많이 이용되고 있으며 capsaicin을 비롯하 여 비타민 A, C 등 다양한 영양성분을 함유하고 있다. 이러 한 영양성분으로 인하여 대사증후군의 예방 및 항암, 항산 화, 항염 효과 등에 관한 다양한 연구가 진행되고 있다(14).

따라서 본 연구에서는 우리나라 사람들이 많이 이용하는 채소 중 하나인 풋고추를 대상으로 이화학적 및 항산화활성 에 대하여 유기재배 및 일반재배 된 풋고추와 비교해보고자 하였다.

\section{재료 및 방법}

\section{재 료}

본 실험에 사용한 유기농 풋고추는 강원도 홍천 $\left(37^{\circ} 49^{\prime} \mathrm{N}\right.$, $\left.128^{\circ} 09^{\prime} \mathrm{E}\right)$ 에서 수확한 것을 사용하였다. 일반재배 한 풋고 추와의 비교를 위하여 일반재배 시료는 유기농 인증을 받은 유기 재배농가의 동일지역, 인근 농가에서 재배되어 수확 된 것을 사용하여 유기 및 일반재배에 따른 시료 간의 기후 등 환경적 조건에서 발생할 수 있는 오차를 줄이고, 객관성 을 확보하였다. 유기 및 일반재배 풋고추 모두 외관 상태와 모양이 전체적으로 균일한 것을 선별하여 시료로 사용하였다.

\section{무게, 길이, 수분함량}

무게는 저울(TS500, TS, Shanghai, China), 길이는 digital caliper (NA500-300S, Bluebird, Seoul, Korea), 수분함량은 수분측정기(FD-720, Kett, Tokyo, Japan)를 이용하여 측정 하였다.

\section{표면색도, 경도}

표면색은 표준백판 $(\mathrm{L}=97.40, \mathrm{a}=-0.49, \mathrm{~b}=1.96)$ 으로 보정 된 chromameter(CR-400, Minolta Co., Osaka, Japan)를 사용 하여 측정하였으며 시료 표면의 중심부위를 Hunter 색차계 인 $\mathrm{L}, \mathrm{a}$ 및 $\mathrm{b}$ 값을 이용하여 측정하였다. 경도는 texture analyser(LLOYD Instrument, Ametek, Inc., Fareham, UK)를 이용하여 측정하였으며 depression limit $10 \mathrm{~mm}$, test speed
$50 \mathrm{~mm} / \mathrm{min}$, trigger $0.1 \mathrm{~N}$ 의 조건에서 측정하였다.

\section{DPPH radical 소거능}

항산화활성 분석을 위한 시료의 추출은 시료를 흐르는 물로 3회 씻은 다음 증류수로 다시 씻은 뒤 분쇄기 (TOKEBI-V8000, BUWON Co., Seoul, Korea)로 분쇄한 후 거즈(대한거즈에이, DAEHAN MEDICAL Co., Suwon, Korea)를 이용하여 큰 덩어리를 거른 착즙액을 ethanol과 동량의 비율로 혼합하여 균질화 한 후 $4,000 \mathrm{rpm}$ 에서 15 분 간 원심 분리하여 상층액을 시료로 사용하였다. $4 \mathrm{mM}$ 의 $\mathrm{DPPH}$ 에탄올 용액을 제조하여 흡광도를 $1.000 \pm 0.1$ 로 조절 하여 사용하였다. $1 \%$ 농도의 시료 $0.2 \mathrm{~mL}$ 를 시험관에 가하 고 $\mathrm{DPPH}$ 용액 $2.8 \mathrm{~mL}$ 를 혼합하여 10 분간 반응시킨 후, $517 \mathrm{~nm}$ 에서 microplate reader(M2, Molecular Device, Sunnyvale, CA, USA)를 이용하여 측정하여 아래의 식으로 부터 DPPH 라디칼 소거활성을 계산하였다(15).

DPPH radical scavenging activity $(\%)=[1-(\mathrm{A} / \mathrm{B})] \times 100$ (A: 시료 첨가구의 흡광도, $\mathrm{B}$ : 시료 무첨가구의 흡광도)

\section{ABTS radical 소거능}

ABTS radical의 소거활성은 $7.4 \mathrm{mM} \mathrm{2,2'-azino-bis}$ (3-ethylbenzthiazoline-6-sulfonic acid; ABTS)와 $2.6 \mathrm{mM}$ potassium persulphate를 하루 동안 암소에 방치하여 ABTS 양이온을 형성시킨 후 이용액을 $735 \mathrm{~nm}$ 에서 흡광도 값이 $1.4 \pm 0.05$ 이 나오도록 buffer로 희석하여 사용하였다. 흡광 도를 맞춘 $\mathrm{ABTS}$ 용액 $190 \mu \mathrm{L}$ 에 $0.1 \%$ 농도의 시료 $10 \mu \mathrm{L}$ 를 가하여 10 분간 반응시키고, $735 \mathrm{~nm}$ 에서 흡광도를 측정하여 아래의 식으로부터 $\mathrm{ABTS}$ 라디칼 소거활성을 계산하였다 (16).

ABTS radical scavenging activity $(\%)=[1-(\mathrm{A} / \mathrm{B})] \times 100$ (A: sample의 흡광도, B: blank solution의 흡광도)

\section{총 페놀 함량}

총 페놀 함량은 Folin-Ciocalteu법(17)을 96-well plate에 맞게 변형하여 비색정량 하였다. 각 추출물 $70 \mu \mathrm{L}$ 에 $2 \mathrm{~N}$ Folin-Ciocalteu 용액 $70 \mu \mathrm{L}$ 를 첨가하여 3 분간 반응시킨 후 $2 \% \mathrm{Na}_{2} \mathrm{CO}_{3} 70 \mu \mathrm{L}$ 를 첨가하여 암소에서 1 시간 방치하였다. Microplate reader(M2, Molecular Device, Sunnyvale, California, USA)를 이용하여 $760 \mathrm{~nm}$ 에서 흡광도를 측정하 여 총 페놀 함량으로 환산하였다. 이 때 추출물에 함유된 총 페놀 함량은 gallic acid를 표준품으로 작성한 표준곡선으 로부터 구하였다.

\section{통계처리}

본 연구결과에 대한 통계처리는 SPSS program(19.0, 
SPSS Inc., Chicago, IL, USA)을 이용하여 평균과 표준편차 로 표시하였으며, t-test 검정을 실시하여 유기 및 일반재배 에 따른 유의성을 검정하였다.

\section{결과 및 고찰}

\section{무게, 길이, 수분함량}

유기농 풋고추와 일반재배 풋고추에 대하여 무게를 비교 한 결과는 Fig. 1과 같으며 유기재배 한 풋고추 무게가 일반 재배 한 풋고추보다 전반적으로 낮았다 $(\mathrm{n}=150)$. 유기농 풋 고추의 무게는 전반적으로 $10 \sim 15 \mathrm{~g}$ 의 범위에서 값을 보였 으며 12 13 g에서 41개, $13 \sim 14 \mathrm{~g}$ 에서 36개 등으로 수량이 많이 분포하였고, 평균값은 $12.38 \mathrm{~g}$ 을 나타내었다. 일반재 배 풋고추의 경우 전반적으로 $12 \sim 20 \mathrm{~g}$ 의 범위에서 값을 보이며 유기농 풋고추보다 높은 무게 값의 분포를 보였으며 $15 \sim 16 \mathrm{~g}$ 에서 31개, 17 18 g에서 30개 등으로 수량이 많았고, 평균값은 $16.13 \mathrm{~g}$ 이었다.

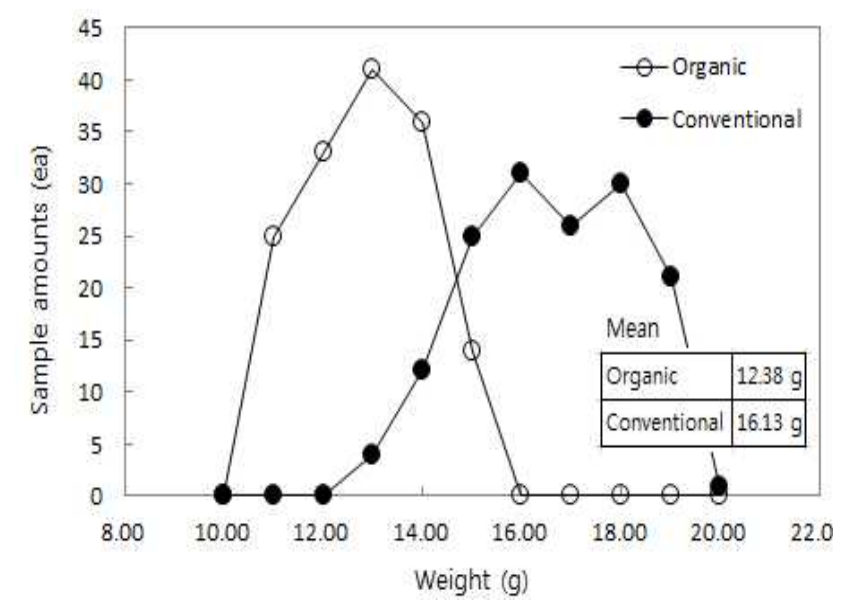

Fig. 1. Comparison of the organic and conventional agricultural cultivation on the weight of green pepper.

풋고추의 길이를 측정한 결과는 Fig. 2 와 같으며 전반적 으로 유기농 풋고추 길이가 일반재배 한 풋고추보다 유의적 으로 짧았다 $(\mathrm{n}=150)$. 유기농 풋고추의 경우 전반적으로 9 14 cm의 범위에서 값을 보였으며 10 11 cm에서 71개, $11 \sim 12 \mathrm{~cm}$ 에서 63개 등으로 수량이 많이 분포하였고, 평균 값은 $10.92 \mathrm{~cm}$ 를 나타내었다. 일반재배 풋고추의 경우 전반 적으로 $10 \sim 15 \mathrm{~cm}$ 의 범위에서 값을 보이며 유기농 풋고추보 다 높은 길이 값의 분포를 보였고, $12 ~ 13 \mathrm{~cm}$ 에서 74개, 11 12 및 13 14 cm에서 각각 35개 등으로 수량이 많았으며 평균값은 $12.47 \mathrm{~cm}$ 이었다. 이상의 결과에서 유기농 풋고추 는 일반재배 풋고추보다 무게는 적고, 길이는 짧은 것으로 조사되었다. 본 실험에서는 일반적인 차이식별을 위하여 무게, 길이에 대한 비교를 하였으며 추후 동일한 품종, 지역
에서의 수확시기에 따른 반복비교가 추가로 진행되어 통계 적으로 분석해 볼 필요가 있다고 사료된다.

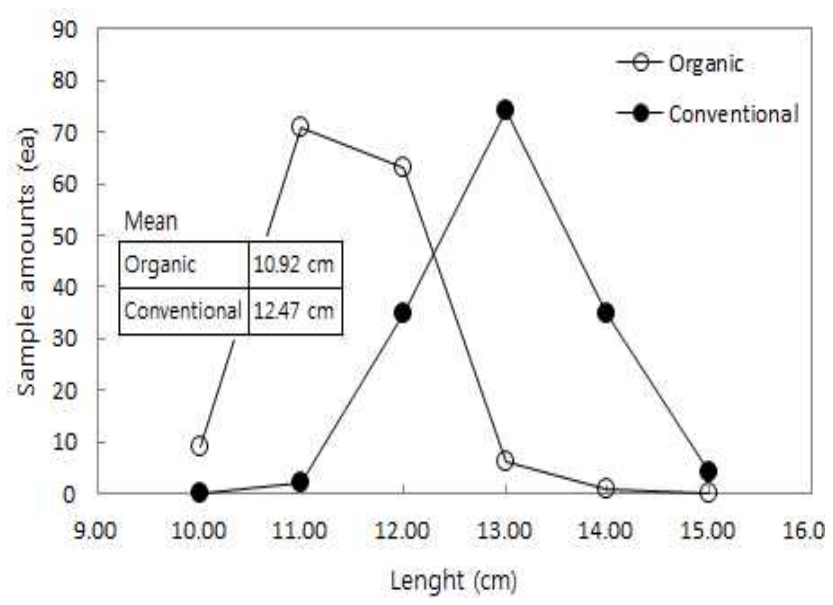

Fig. 2. Comparison of the organic and conventional agricultural cultivation on the length of green pepper.

수분함량은 품질의 조직감, 영양성분 함량 등에 영향을 끼칠 수 있으며 본 연구에서는 재배조건에 따른 풋고추의 수분함량 차이를 알아보고자 하였다. 그 결과 유기농 풋고 추가 $91.78 \%$, 일반재배 풋고추가 $90.04 \%$ 로 유기농 풋고추 의 수분함량이 다소 높았으며(Fig. 3) 두 시료 간 유의적 차이를 보였다( $\mathrm{p}<0.05)$.

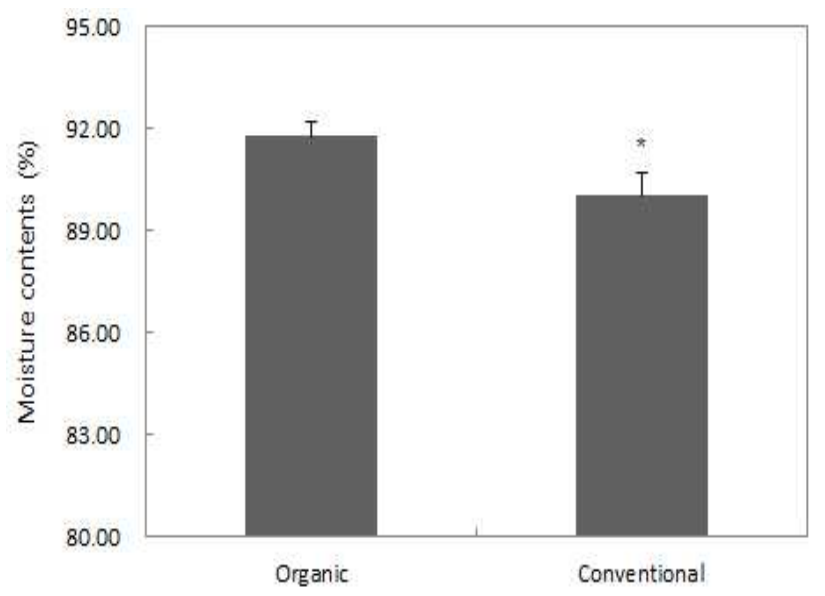

Fig. 3. Comparison of the organic and conventional agricultural cultivation on the moisture contents of green pepper.

${ }^{*} \mathrm{p}<0.05: \mathrm{t}$-test between the conventional cultivation and the organic cultivation.

\section{표면색도, 경도}

유기 및 일반재배 풋고추의 표면색은 Hunter's color value 인 $\mathrm{L}, \mathrm{a}, \mathrm{b}$ 값을 이용하였고, 측정 결과를 Table 1 에 나타내었 다. L값은 유기농 36.72 , 일반재배 33.98 의 값을 나타내어 유기농 풋고추가 좀 더 밝은 값을 나타내었고, $\mathrm{a}$ 값에 있어서 는 유기농 -12.05 , 일반재배 -9.03 으로 유기농 풋고추가 다 
소 초록색을 띠는 것으로 조사되었다. $\mathrm{b}$ 값의 경우 유기농 13.35 , 일반재배 10.49 를 나타내었으며 $\mathrm{L}, \mathrm{a}, \mathrm{b}$ 값에서 모두 유의적인 차이를 보였다(p<0.001). Choi 등(3)이 연구한 유 기 및 일반재배 된 배의 표면색 비교에서도 $\mathrm{L}$ 및 $\mathrm{b}$ 값이 일반 과실에 비하여 낮고, $\mathrm{a}$ 값은 높게 나타났으며 유의적인 차이를 보였다고 하였다.

Table 1. Comparison of the organic and conventional agricultural cultivation on the color of green pepper

\begin{tabular}{ccc}
\hline & Organic & Conventional \\
\hline $\mathrm{L}$ & $36.72 \pm 2.17^{1)^{* * *}}$ & $33.98 \pm 2.08$ \\
$\mathrm{a}$ & $-12.05 \pm 2.02^{* * *}$ & $-9.03 \pm 1.94$ \\
$\mathrm{~b}$ & $13.35 \pm 2.62^{* * *}$ & $10.49 \pm 1.69$ \\
\hline
\end{tabular}

${ }^{1)}$ Data represents mean \pm SD.

${ }^{* * *} \mathrm{p}<0.001$ : $\mathrm{t}$-test between the conventional cultivation and the organic cultivation.

유기농 풋고추와 일반재배 풋고추에 대하여 경도를 비교 한 결과는 Fig. 4와 같으며 유기농 풋고추는 $6.73 \mathrm{~N}$, 일반재 배 풋고추는 $5.62 \mathrm{~N}$ 으로 측정되어 유기농 풋고추의 경도 값이 다소 높았으나 유의적인 차이는 없었다. 유기 및 일반 재배 간 품질특성을 보이는 이유는 농약 및 화학비료 사용 유무 등 서로 다른 재배환경 때문이라고 사료된다.

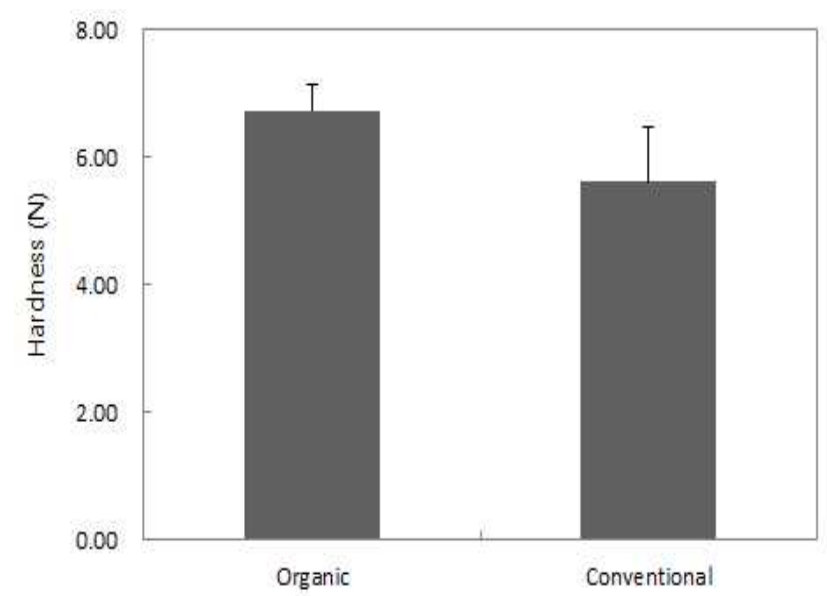

Fig. 4. Comparison of the organic and conventional agricultural cultivation on the hardness of green pepper.

\section{DPPH 및 ABTS radical 소거능, 총 페놀 함량}

항산화 물질의 가장 특징적인 역할은 oxidative free radical과 반응하는 것으로 이것을 이용하여 항산화능을 측 정하게 되며 본 연구에서는 풋고추에 대한 항산화능을 측정 하였다. DPPH는 천연소재로부터 항산화활성을 분석하는 데 많이 이용되며 비교적 안정한 free redical로서 항산화제, 방향족 아민류 등에 환원되어 색이 탈색되는 원리를 이용하 여 측정하게 된다(18). 또한 $\mathrm{ABTS}$ radical 소거능은 $\mathrm{ABTS}$ 와 potassium persulfate가 반응하여 ABTS cation radical이
생성되면 청록색을 띠게 되는데 이때 항산화물질과 반응하 여 ABTS cation radical이 소거되면서 청록색이 탈색된다. 따라서 높은 탈색율을 보일수록 우수한 항산화 활성을 기대 할 수 있다(19). 본 연구에서 DPPH 및 ABTS radical 소거능 을 조사한 결과는 Table 2 와 같으며 DPPH radical 소거능의 경우 유기농 풋고추 $64.10 \%$, 일 반재배 풋고추 $62.72 \%$ 로 다소 유기농 풋고추의 활성이 높았으며 유의적인 차이를 보였다(p<0.001). ABTS radical 소거능에서는 유기농 풋고 추 $51.06 \%$, 일반재배 풋고추 $52.86 \%$ 로 일반재배 풋고추의 활성이 높았고, 유의적인 차이를 보였다( $<<0.001)$. Choi 등 (3)이 연구한 유기재배와 일반재배 된 배의 DPPH radical 소거능에서 일반적으로 유기농 과실에서 다소 높은 경향이 나타났다고 보고하여 본 결과와 유사하였다. Yoon 등(14) 은 풋고추, 꽈리고추, 오이고추, 청양고추 등 종류별 청고추 의 항산화 효과를 비교하였으며 그 중 풋고추의 DPPH radical 소거능의 경우 $1000 \mathrm{\mu g} / \mathrm{mL}$ 농도에서 약 10 33\%의 소거활성을 나타내었고, ABTS radical 소거능에서는 1000 $\mu \mathrm{g} / \mathrm{mL}$ 농도에서 약 10 20\%의 소거활성을 보여 본 결과와 는 다소 차이가 있었다. 이는 같은 시료라 하더라도 품종, 수확시기, 추출조건 등에 따라 결과가 다를 수 있기 때문이 라 사료된다.

Table 2. Comparison of the organic and conventional agricultural cultivation on the DPPH and ABTS radical scavenging activity of green pepper

\begin{tabular}{lcc}
\hline & Organic & Conventional \\
\hline DPPH radical scavenging activity (\%) & $64.10 \pm 2.17^{1)^{* * *}}$ & $62.72 \pm 2.08$ \\
ABTS radical scavenging activity (\%) & $51.06 \pm 2.62^{* * *}$ & $52.86 \pm 1.69$ \\
\hline
\end{tabular}

${ }^{11)}$ Data represents mean \pm SD.

${ }^{* * *}<0.001$ : t-test between the conventional cultivation and the organic cultivation.

페놀성 화합물은 다양한 식물성 식품에 존재하는 것으로 알려져 있으며 구조식에 phenolic hydroxyl $(\mathrm{OH})$ 기를 소유 하고, 고명 안정화된 구조로서 전자를 수용하는 기작으로 항산화 반응에 직접적으로 관여한다(20). 또한 페놀성 화합 물은 단백질, 2 가 금속이온, 기타 거대 분자들과 결합하는 성진과 높은 항산화 효과를 가지는 것으로 알려져 있어 총 페놀함량이 높다면 항산화 효과가 우수할 것이라 예상할 수 있다. 이에 풋고추의 총 페놀 함량을 측정하였으며 유기 농 및 일반재배에 따른 결과는 Fig. 5 와 같다. 유기농 풋고추 는 $144.56 \mathrm{ug} / \mathrm{g}$, 일반재배 풋고추는 $140.78 \mathrm{ug} / \mathrm{g}$ 으로 유기농 풋고추의 총 페놀 함량이 높았으나 본 연구에서는 재배 차이에 따른 유의적인 차이는 보이지 않았다. 일반적으로 소비자들은 유기농으로 재배된 과실이 건강에 이로우며 친환경적이고, 맛과 무기질 등이 많다고 믿고 있다(21). 그 러나 Rosen과 Allan(22)은 이러한 결과가 일관성 있는 것은 아니라고 하였으며 그 예로 Lombardi-Boccia 등(23)은 유기 
재배 한 자두가 일반재배 한 경우보다 플라보노이드와 비타 민 함량이 높았으나 페놀화합물과 quercetin의 함량은 적었 다고 보고하였다. 총 페놀 함량은 그 식품의 총 항산화 활성 에 기여하는 바가 매우 높다고 알려져 있는데(24) 추후 풋고 추의 생리활성효과에 대한 연구를 통해 유기 및 일반재배 풋고추와의 차별성 구명이 필요하다고 판단된다. 또한, 유 기재배 한 풋고추에서 환경스트레스인 병충해로 인한 품질 저하 요인과 함께 이차대사물질 생산 등 항산화 작용과의 연계 가능성 여부에 대한 연구도 진행해 볼 필요가 있다고 사료된다.

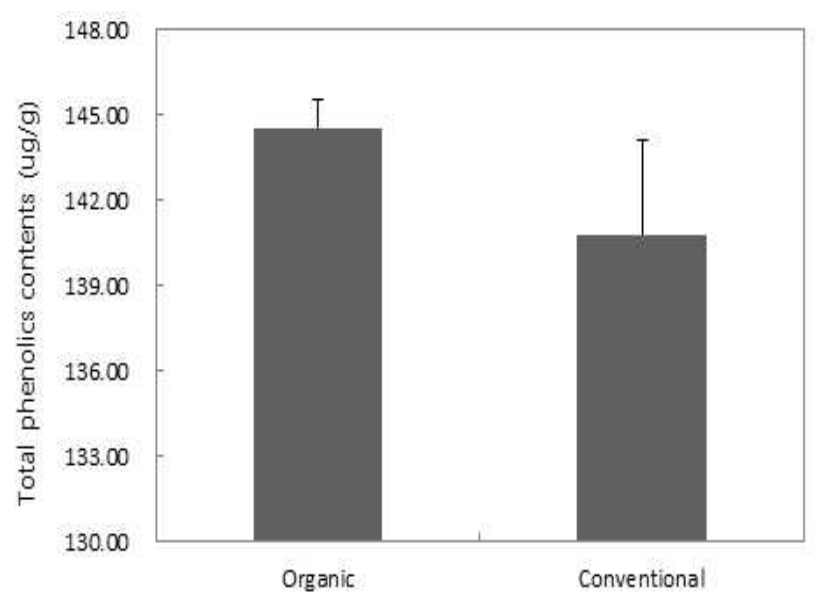

Fig. 5. Comparison of the organic and conventional agricultural cultivation on the total phenolics contents of green pepper.

\section{요 약}

유기 및 일반재배에 따른 풋고추의 이화학적 품질특성 및 항산화활성을 비교하고자 무게, 길이, 수분함량, 표면색 도, 경도, DPPH 및 $\mathrm{ABTS}$ radical 소거능, 총페놀함량 등을 분석하였다. 무게, 길이의 경우 전반적으로 유기농 풋고추 에서 무게가 적고, 길이가 짧았으며 수분함량의 경우 유기 및 일반재배 간 비슷한 값을 나타내었다. 표면색에 있어서 유기농 풋고추의 $\mathrm{L}$ 과 $\mathrm{b}$ 값이 높았고, $\mathrm{a}$ 값은 일반재배 풋고추 의 값이 높았으며 재배조건에 따른 $\mathrm{L}, \mathrm{a}, \mathrm{b}$ 값의 유의적인 차이를 보였다. 항산화활성의 경우 DPPH radical 소거능은 유기농 풋고추가, ABTS radical 소거능은 일반재배 풋고추 가 높은 활성을 보였다. 총 페놀 함량은 유기농 풋고추 값이 높았으나 유의적 차이를 보이지 않았다. 본 연구에서는 무 게, 길이 등의 외적 품질에 대해서 일반재배 풋고추의 값이 높았고, 항산화활성에 대해서는 전반적으로 유기농 풋고추 에서 다소 높은 활성을 보였으나 유기 및 일반재배에 따른 내외적 품질비교를 위해서 더 많은 분석이 추가로 진행되어 야 할 필요가 있다고 사료된다.

\section{감사의 글}

본 연구는 농림수산식품부 농림기술개발사업의 연구비 지원(313030-03-2-HD040)을 받아 수행된 연구로 이에 감사 드립니다.

\section{References}

1. Kim CG, Jeong HG, Moon DH (2013) Demand for organic farming technology and roadmap for technology development. Report of KREI, p 1-31

2. Choi JE, Kim YG (2011) The relationships of consumers' objective knowledge, subjective knowledge, risk perception and purchase intention of organic food : a mediating effect of risk perception towards food safety. Korean J Culinary Res, 17, 153-168

3. Choi HS, Lee X, Kim WS, Lee Y (2010) Comparison of fruit quality and antioxidant compound of 'Niitaka' pear trees grown in the organically and conventionally managed systems. Korean J Environ Agri, 29, 367-373

4. Treutter D (2001) Biosynthesis of phenolic compounds and its regulation in apple. Plant Growth Regulators, 34, 71-89

5. Nam KS, Lee JY, Kim KD (2007) A study on the recognition of organic food of housewives in Seoul area. Korean J Food Preserv, 14, 676-680

6. Sohn HJ (2008) A study on the perception of the organic agricultural products and the state of purchasing them among housewives. MS Thesis. Sangji University, Gangwon-do, Korea

7. Choi JS (2013) A study of environment-friendly food development factors for consumers to improve the reliability. MS Thesis. MyongJi University, Seoul, Korea

8. Ock HS, Pyon JY (2011) Trend and perspective of weed control techniques in organic farming. Korean $\mathrm{J}$ Weed Sci, 31, 8-23

9. Yun HJ, Park KH, Ryu KY, Kim BS (2013) Analyses of microbiological contamination in cultivation and distribution stage of tomato and evaluation of microbial growth in tomato extract. J Food Hygiene Safety, 28, 174-180

10. Jo MJ, Jeong AR, Kim HJ, Lee NR, Oh SW, Kim YJ, Chun HS, Koo MS (2011) Microbiological quality of fresh-cut produce and organic vegetables. Korean J Food Sci Technol, 43, 91-97

11. Kim KD (2010) Analysis of heavy metals in organic 
and non-organic vegetables. J Korean Soc Environ Analysis, 13, 21-25

12. Kim HY, Lee KB (2004) Content of pesticide contaminants content in organic vegetables. Korean J Food Preserv, 11, 57-62

13. Kang JS, Cho HR, Han JS, Hur SH (2003) Hot water dipping treatment to improve storage quality of green red pepper. Korean J Food Preserv, 10, 261-266

14. Yoon HJ, Lee S, Hwang IK (2012) Effects of green pepper (Capsicum annuum var.) on antioxidant activity and induction of apoptosis in human breast cancer cell lines. Korean J Food Sci Technol, 44, 750-758

15. Santoru K, Kazuhiko T, Nori M, Jinetsu U (2002) Antioxidative activity of apple skin or flesh extracts associated with fruit development on selected apple cultivars. Sci Hort, 96, 177-185

16. Woo KS, Seo MC, Kang JR, Ko JY, Song SB, Lee JS, Oh BG, Park GD, Lee YH, Nam MH, Jeong HS (2010) Antioxidant compounds and antioxidant activities of the methanolic extracts from milling fractions of sorghum (Sorghum bicolor L. Moench). Korean Soc Food Sci Nutr, 39, 1695-1699

17. Florence CRF, Pascale MG, Jacques JN (1992) Cysteine as an inhibitor of enzymatic browning. 2. Kinetic studies. J Agric Food Chem, 40, 2108-2113
18. Lee SG, Yu MH, Lee SP, Lee IS (2008) Antioxidant activities and induction of apoptosis by methanol extracts from avocado. J Korean Soc Food Sci Nutr, 37, 269-275

19. Chung HJ, Jeon IS (2011) Antioxidative activities of methanol extracts from different parts of Chrysanthemum zawadskii. Korean J Food Preserv, 18, 739-745

20. Giacosa A, Filiberti R (1996) Free radicals, oxidative damage and degenerative disease. Eur J Prev, 5, 307-312

21. Saba A, Messina F (2003) Attitudes towards organic foods and risk/benefit perception associated with pesticides. Food Quality and Preference, 14, 637-645

22. Rosen CJ, Allan DL (2007) Exploring the benefits of organic nutrient sources for crop production and soil quality. HortTech, 17, 422-430

23. Lombardi-Boccia G, Lucarini M, Lanzi S, Aguzzi A, Cappelloni M (2004) Nutrients and antioxidant molecules in yellow plums (Prunus domestica L.) from conventional and organic productions : a comparative study. J Agri Food Chem, 52, 90-94

24. Winston GW, Giulioz RT (1991) Prooxidant and antioxidant in aquatic organisms. Aquat Toxicol, 19, 137-161 